\title{
A review of cervical lymph node biopsies performed at Royal Lancaster Infirmary
}

\author{
Eleanor Farrar, MRCS; Mohamed Baraka, FRCS
}

\section{INTRODUCTION}

This is a retrospective audit of all cervical lymph node biopsies performed in the ENT department at Royal Lancaster Infirmary (RLI) over the two-year period 2007 to 2008.

\section{Aims}

To review all cervical lymph node biopsies and establish if the

following standards had been met:

I. Was a pre-operative flexible nasolaryngoscopy examination performed prior to surgery?

2. Was the case discussed with haematology or oncology multidisciplinary teams (MDTs) prior to surgery?

3. Was fine-needle aspiration cytology (FNAC) performed prior to surgery?

Additional objectives included reviewing referral patterns, indication for surgery and final outcomes of patients requiring cervical lymph node biopsies.

\section{Background}

Persistent cervical lymphadenopathy is a common presentation to the ENT clinic. While most of these are benign, an enlarged lymph node in the neck may represent the first presentation of a more serious underlying pathology such as tuberculosis or malignancy. This article aims to review cases of cervical lymphadenopathy that required biopsy, in particular looking at referral patterns, investigations and final diagnoses.

An open lymph node biopsy may be required to confirm diagnosis, but is usually only performed if other diagnostic tests such as FNAC have not yielded sufficient information. Biopsies are also performed on lymphoma patients to provide histological subtyping which guides treatment and is of prognostic significance.

Open cervical lymph node biopsies have an associated morbidity, including scarring, bleeding, wound infection, and damage to nerves, in particular the accessory nerve. (1) It also alters lymphatic drainage pathways in the neck, though this is not thought to impair outcomes for patients who are found to have metastatic nodal disease (2) $^{(2)}$ In suspected head and neck cancer, a thorough examination for a primary tumour should be performed. Open biopsy of a cervical node is usually reserved for patients where there is no evidence of a primary lesion.

\section{Methods}

Patients were identified retrospectively from the pathology database at RLI. Patients with a cervical lymph node biopsy performed by the ENT team from I January 2007 to 31 December 2008 were identified and included in the audit.

\section{Audit Standards}

The 2004 NICE Guidelines on Improving Outcomes in Head and Neck Cancer ${ }^{(3)}$ make several recommendations relevant to open lymph node biopsy, and we audited our data against the following standards:

1. Any patient with an isolated neck lump should first be examined by flexible endoscopy.

2. No patient should undergo surgical excision or core biopsy of an enlarged lymph node without preliminary discussion with a haematologist or oncologist.

3. FNAC should be available in the clinic at the time of initial assessment of a neck lump.

\section{RESULTS}

Thirty-eight patients were identified, with an age range of 14 to 69 years and a mean age of 44 years. The majority (22) of these patients were referred from general practice (GP), of whom II were referred urgently, ten were routine referrals, and one was referred as an emergency. Six patients were referred from the haematology team and the remainder from a mixture of mostly medical hospital specialties (see table I)

\begin{tabular}{|c|c|c|}
\hline Referral sources & $\begin{array}{c}\text { No. of } \\
\text { patients }\end{array}$ & Eventual diagnosis (no. of patients) \\
\hline $\begin{array}{l}\text { GP: two-week } \\
\text { urgent referral }\end{array}$ & 11 & $\begin{array}{l}\text { Head and neck squamous cell cancer (I) } \\
\text { Papillary thryoid carcinoma (I) } \\
\text { Lymphoma (3) } \\
\text { Kikuchi's lymphadenitis (I) } \\
\text { Reactive (4) } \\
\text { ?Tuberculosis (I) }\end{array}$ \\
\hline GP: routine & 10 & $\begin{array}{l}\text { Head and neck malignancies (2) } \\
\text { Lymphoma (I) } \\
\text { Tuberculosis (1) } \\
\text { Recurrent sialadenitis (1) } \\
\text { Parotid adenoma (1) } \\
\text { Reactive (2) } \\
\text { Benign other (2) }\end{array}$ \\
\hline GP: emergency & । & Reactive (I) \\
\hline$A \& E$ & 1 & Reactive (I) \\
\hline Haematology & 6 & $\begin{array}{l}\text { Lymphoma (4) } \\
\text { Small cell cancer lung (1) } \\
\text { Reactive (1) }\end{array}$ \\
\hline Respiratory & 4 & $\begin{array}{l}\text { Lymphoma (3) } \\
\text { Smail cell cancer lung (I) }\end{array}$ \\
\hline Gastroenterology & 2 & $\begin{array}{l}\text { Metastatic cancer prostate (I) } \\
\text { Lymphoma (I) }\end{array}$ \\
\hline General surgery & 1 & Reactive (I) \\
\hline Acute medicine & 1 & Lymphoma (I) \\
\hline Private patient & 1 & Lymphoma (I) \\
\hline
\end{tabular}


Table I demonstrates the spread of referrals to ENT and relates this to the final outcome. Forty-five percent of those referred urgently had malignancy, compared to $30 \%$ of the routine GP referrals.

The duration of the neck lump at time of presentation to ENT ranged from one week to one year, with a mean 13 weeks (data available for 30 patients). In addition, a neck lump was an incidental examination finding by the referring doctor for six further patients.

\section{Audit standard I}

The first audit standard was to look at whether or not flexible endoscopy was performed prior to surgery (see table 2). Casenote review showed evidence that this had been performed for 28 patients, with no indication that it had been performed for a further six patients. Sufficient information to judge this was unavailable for four patients.

\begin{tabular}{|l|c|l|}
\hline $\begin{array}{l}\text { Flexible } \\
\text { nasolaryngoscopy }\end{array}$ & $\begin{array}{c}\text { No. of } \\
\text { patients }\end{array}$ & $\begin{array}{l}\text { Eventual diagnosis } \\
\text { (no. of patients) }\end{array}$ \\
\hline Performed & 28 & \\
\hline Not performed & 6 & $\begin{array}{l}\text { Lymphoma (3) } \\
\text { Salivary adenoma (1) } \\
\text { Recurrent sialadenitis (1) } \\
\text { Possible tuberculosis (1) }\end{array}$ \\
\hline Data not recorded & 4 & \\
\hline \multicolumn{2}{|c|}{ Table 2 Flexible nasolaryngoscopy } \\
\hline
\end{tabular}

\section{Audit standard 2}

The second standard looked at the involvement of oncology or haematology teams prior to surgery. Table 3 shows that of the 25 cases where malignancy was suspected there was documented discussion with either the oncology or haematology team prior to surgical excision in nine cases. Of the remaining 13 cases, one was eventually found to be a lymphoma and the rest were benign.

\section{Audit standard 3}

The third standard looked at the availability and use of FNAC prior to surgical excision. Eighteen patients had FNA performed, the results of which are documented in table 4 .

\begin{tabular}{|l|l|}
\hline Result & No. of patients \\
\hline C1 inadequate & 1 I \\
\hline C2 benign & 1 \\
\hline C3 atypia probably benign & 2 \\
\hline C4 suspicious of malignancy & I \\
\hline C5 malignant & I (Papillary thyroid cancer) \\
\hline Other & I (? Lymphoma) \\
I (Result unavailable)
\end{tabular}

\begin{tabular}{|l|l|}
\hline Diagnosis & No. of patients \\
\hline Lymphoma & 12 \\
\hline Head and neck malignancy & $\begin{array}{l}3 \text { (Squamous cell cancer) } \\
1 \text { (Papillary thyroid cancer) }\end{array}$ \\
\hline Other malignancy & $\begin{array}{l}\text { (Metastatic prostate cancer) } \\
\text { (Small cell lung cancer) }\end{array}$ \\
\hline Tuberculosis & 2 \\
\hline Reactive & 9 \\
\hline Benign other & I (Kikuchi's lymphadenitis) \\
\hline \multicolumn{2}{|c|}{ Table 5. Summary of diagnostic outcomes } \\
\hline
\end{tabular}

\section{DISCUSSION}

\section{Referral patterns}

Of the eight patients referred from GP who were subsequently confirmed to have malignancy, five had been referred urgently and three routinely. The proportion of urgent GP referrals found to be malignant was $45 \%$, compared to

\begin{tabular}{|c|c|c|c|c|}
\hline Indication for biopsy & $\begin{array}{l}\text { No. of } \\
\text { patients }\end{array}$ & $\begin{array}{l}\text { FNA } \\
\text { performed? }\end{array}$ & $\begin{array}{l}\text { Discussed with relevant } \\
\text { MDT? (no. of patients) }\end{array}$ & $\begin{array}{l}\text { Eventual diagnosis } \\
\text { (no. of patients) }\end{array}$ \\
\hline Suspected metastases of known primary cancer & 1 & 0 & Oncology (1) & $\begin{array}{l}\text { Confirmed metastatic } \\
\text { cancer prostate ( } 1 \text { ) }\end{array}$ \\
\hline Suspected lymphoma & 14 & $\begin{array}{l}4 \\
(2 \times C l, 1 \times C 4 \\
\text { I?lymphoma })\end{array}$ & Haematology (7) & $\begin{array}{l}\text { Reactive (2) } \\
\text { Lymphoma (10) } \\
\text { Small cell lung (1) } \\
\text { Kikuchi's lymphadenitis (1) }\end{array}$ \\
\hline Other suspected malignancy & 10 & $\begin{array}{c}8 \\
(4 \times C 1, I \times C 2 \\
I \times C 3, I \times C 5 \\
\text { I unknown })\end{array}$ & Oncology (1) & $\begin{array}{l}\text { Lymphoma (4) } \\
\text { Head and neck squamous } \\
\text { cell cancer ( } 3 \text { ) } \\
\text { Cancer thyroid (I) } \\
\text { Small cell lung (I) } \\
\text { Benign reactive (1) }\end{array}$ \\
\hline Parotid mass & 2 & $\mathrm{I}(\mathrm{Cl})$ & N/A & Reactive (2) \\
\hline Recurrent sialadenitis & 1 & 0 & N/A & Recurrent sialadenitis ( 1 ) \\
\hline Suspected tuberculosis or other & 10 & $(4 \times C l, I \times C 3)$ & N/A & $\begin{array}{l}\text { Benign reactive (5) } \\
\text { Possible sarcoid (1) } \\
\text { Possible toxoplasmosis (I) } \\
\text { Lymphoma (I) } \\
\text { Tuberculosis (2) }\end{array}$ \\
\hline \multicolumn{5}{|c|}{ Table 3 Indication for surgery and pre-operative MDT involvement } \\
\hline
\end{tabular}


$30 \%$ of the routine referrals. However, these figures represent a very selective group of patients in whom an obvious primary malignancy was not evident at presentation and who therefore required invasive investigation. It is therefore not possible to comment generally on the appropriateness of urgent versus routine GP referrals to ENT from this data alone. It does, however, highlight the benefit of short clinic waiting times for routine referrals, not just urgent ones.

It also of interest to note the role of the ENT department in diagnosing lymphoma, both in conjunction with the haematology department but also with other medical specialties. It can be seen from Table I that not all patients referred by the haematology team with suspected lymphoma do in fact have the disease, and that of the 12 patients found to have lymphoma, eight were referred from specialties other than haematology.

\section{Adherence to pre-operative standards}

\section{Audit standard I: flexible endoscopy}

Of the 34 patients for whom data was available, 28 had flexible endoscopy performed. This included all the patients subsequently found to have metastatic head and neck sqaumous cell carcinoma, as per the NICE Guidelines. Guidelines are specifically for patients with an isolated neck lump, and it is likely that the one tuberculosis patient and three lymphoma patients who did not have this examination prior to surgery in fact had multiple cervical lymphadenopathy.

Nevertheless, flexible nasolaryngoscopy is considered to be an integral part of a routine ENT examination. Some patients refuse flexible nasendoscopy and where this is the case it needs to be documented.

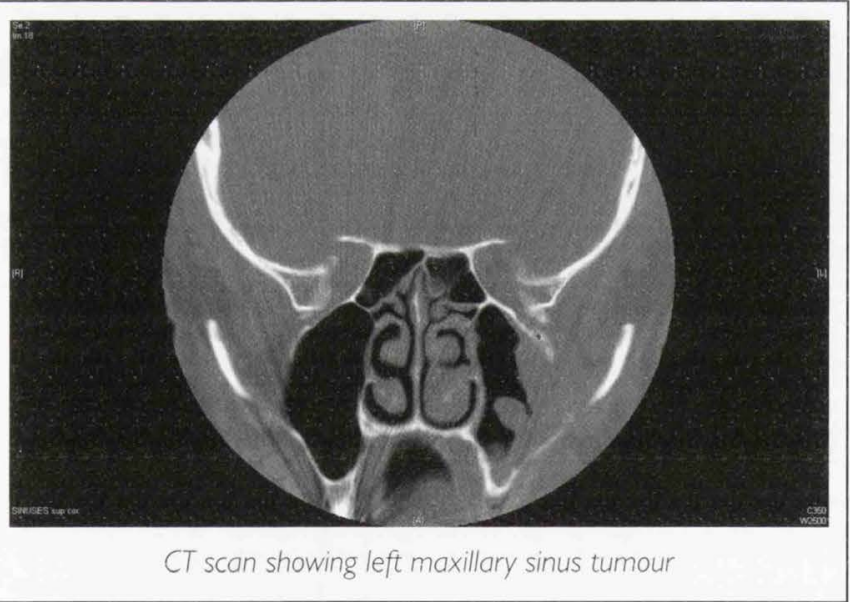

Audit standard 2: discussion with haematology or oncology prior to surgery in suspected malignancy

Pre-operative discussion with the haematology team was documented for seven of the 14 suspected cases. Of the II cases of suspected non-haematological malignancy, two were discussed with oncology pre-operatively. One of these had a known prostatic primary with clinical suspicion of further dissemination. With the benefit of hindsight, perhaps it would have been better to discuss those patients who had clinically suspicious nodes with an MDT prior to excision, as the clinical suspicion of malignancy was confirmed in $90 \%$ of these cases. It is difficult to say whether this would have altered the surgical course for these patients, but it may have allowed for further imaging, for example magnetic resonance imaging of the head and neck or positron emission tomography scan, or further minimal intervention investigations such as ultrasound-guided FNAC or core biopsy. However, excision at least allowed for a rapid histological diagnosis without delay for further investigations.

Audit standard 3: FNAC should be available in the clinic at the time of initial assessment of a neck lump

FNAC has been available in the ENT outpatients department throughout the time proposed; however, it does not seem to have been performed in each case. The diagnostic yield from FNAC in the patients reviewed in this study is less than that we might have hoped for. It is possible that this low diagnostic success rate of this procedure has discouraged more extensive use of this investigation. Success rate is dependent on operator technique when taking the sample and on cytological processing methods. ${ }^{(4)}$ The rate of obtaining a diagnostic aspirate may be increased by using ultrasound-guided techniques or core biopsy.

\section{CONCLUSION}

Open cervical lymph node biopsy remains an important diagnostic procedure that demonstrated histological confirmation of malignancy in 55\% of patients. However, the procedure is not without risks, and improved sampling techniques such as ultrasound-guided FNAC and core biopsy and cytological methods, including liquid-based cytology and immunohistochemistry, may help patients to be diagnosed quickly and without the need for open biopsy.

\section{REFERENCES}

I. Gooder P, Palmer M. Cervical lymph node biopsy - a study of its morbidity. J Larangol Otol 1984:98( I 0): 1031-40

2. Robbins KT, Cole R, Marvel J, Fields R, Wolf P, Goepfert H. The violated neck: cervical node biopsy prior to definitive treatment. Otolaryngol Head Neck Surg 1986;94(5):605- 10

3. National Institute of Clinical Excellence. Improving Outcomes in Head and Neck Cancer. NICE: 2004

4. Sigstad E, Dong HP, Davidson B, Berner A, Tierens A, Risberg B. The role of flow cytometric immunophenotyping in improving the diagnostic accuracy in referred fine-needle aspiration specimens. Diagn Cytopathol 2004:31 (3): 159-63

5. Knappe M, Louw M, Gregor RT. Ultrasonography-guided fine-needle aspiration for the assessment of cervical metastases. Arch Otolaryngol Head Neck Surg 2000; | 26(9): 109|-6

6. Robinson IA, Cozens NJ. Does a joint ultrasound guided cytology clinic optimize the cytological evaluation of head and neck masses? Clin Radiol 1999;54(5):312-6 